\title{
Zastosowanie metody kategoryzacji do oceny dojrzałości procesowej na przykładzie procesu zarządzania ryzykiem
}

\author{
Dr hab. Beata Domańska-Szaruga, prof. UPH \\ Uniwersytet Przyrodniczo-Humanistyczny w Siedlcach \\ Wydział Nauk Społecznych, Instytut Nauk o Zarządzaniu i Jakości \\ Dr Wioletta Wereda \\ Wojskowa Akademia Techniczna w Warszawie, Wydział Bezpieczeństwa \\ Logistyki i Zarządzania, Instytut Organizacji i Zarządzania
}

\section{Wprowadzenie}

Ocena dojrzałości procesowej organizacji oraz dojrzałości poszczególnych jej procesów jest działaniem pracochłonnym, dlatego warto poszukiwać w tym obszarze rozwiązań, które będą mało skomplikowane, a jednocześnie będą dostarczać wystarczającą ilość informacji i pozwalać na maksymalnie obiektywną ocenę. Ważne jest też to, aby te rozwiązania i metody pozwalały na samoocenę dojrzałości procesowej, na wskazanie obszarów wymagających doskonalenie oraz nie były czasochłonne czy kosztowne. Tematyka samooceny dojrzałości procesowej ma ogromne znaczenie dla organizacji, które starają się stale doskonalić w dzisiejszym, konkurencyjnym świecie. Na korzyści z samooceny wskazują między innymi Gabryelczyk $^{1}$, Kwintowski ${ }^{2}$, Ritchie i Dale ${ }^{3}$ oraz Warwood i Antony ${ }^{4}$. Akcentują oni korzyści polegające na inicjowaniu działań korygujących i integrujących, które mają

1 R. Gabryelczyk, Samoocena w badaniu dojrzałości procesowej organizacji: studium empiryczne, „Ekonomika i Organizacja Przedsiębiorstwa” 2016, nr 12, s. 67-78.

2 A. Kwintowski, Samoocena jako narzędzie doskonalenia, „Prace Naukowe Uniwersytetu Ekonomicznego we Wroctawiu" 2015, nr 376, s. 346-356.

3 L. Ritchie, B.G. Dale, Self-assessment using the business excellence model: A study of practice and process, „International Journal of Production Economics” 2000, vol. 66, s. 241-254.

4 S. Warwood, J. Antony, A simple, semi-prescriptive self-assessment model for TQM, „Quality Assurance" 2003, vol. 10, s. 67-81. 
na celu podnoszenie dojrzałości procesów i obszarów procesowych wymagających poprawy. Dodatkowo samoocena rozwija wśród pracowników zrozumienie i świadomość zagadnień związanych z wprowadzaniem zarządzania procesowego.

Celem artykułu jest przedstawienie takiej metody oceny dojrzałości procesów, która jest metodą mało skomplikowaną i możliwą do zastosowania w organizacjach dowolnego typu czy branży. Jest to metoda kategoryzacji. W opracowaniu zaprezentowano również wyniki badań dojrzałości procesu zarządzania ryzykiem w urzędach podstawowych jednostek samorządu terytorialnego w Polsce, przeprowadzonych w 2018 roku i opracowanych z wykorzystaniem metody kategoryzacji. Zaprezentowane analizy są elementem szerszych badań nad kulturą zarządzania ryzykiem w organizacji i efektem uczestnictwa autorek w procesach budowy systemów zarządzania w organizacjach publicznych.

\section{Dojrzałość procesowa organizacji - aspekty teoretyczne}

Problematyka dojrzałości procesowej organizacji staje się coraz bardziej popularna w badaniach naukowych. Wiedza na temat pomiaru dojrzałości procesowej oraz korzyści czerpanych z przechodzenia organizacji na coraz to wyższy poziom dojrzałości wykorzystywana jest z powodzeniem w praktyce zarządzania organizacjami.

Dojrzałość procesowa jest miarą zaawansowania organizacji w stosowaniu metod i narzędzi zarządzania procesami oraz miarą doskonałości realizacji poszczególnych procesów ${ }^{5}$. Jest to stan systemu, w którym świadomie dyskontuje się korzyści osiągane z poziomu zaawansowania zastosowanych rozwiązań procesowych ${ }^{6}$. Dojrzałość procesowa organizacji wyraża się zakresem, w jakim procesy są formalnie zdefiniowane, zarządzane, elastyczne, mierzone i efektywne ${ }^{7}$. Cechy te są naturalnie stopniowalne - od organizacji niedojrzałej do dojrzałej w zakresie wdrożenia danych procesów. W ocenie dojrzałości procesowej organizacji pomocne są modele dojrzałości, które zawierają sekwencje kolejnych poziomów (stopni) obrazujących pożądaną lub logiczną ścieżkę przechodzenia od stanu początkowego

5 M. Röglinger, J. Pöppelbuß, J. Becker, Maturity models in business process management, „Business Process Management Journal” 2012, vol. 18, no. 2, s. 328-346.

6 P. Grajewski, Procesowe zarzq̨dzanie organizacjq, Polskie Wydawnictwo Ekonomiczne, Warszawa 2012, s. 90.

7 P. Grajewski, Organizacja procesowa, Polskie Wydawnictwo Ekonomiczne, Warszawa 2007, s. 119. 
do pełnej dojrzałości ${ }^{8}$. Aktualnie w literaturze istnieje co najmniej kilkadziesiąt modeli dojrzałości procesowej o różnym stopniu szczegółowości ${ }^{9}$. Stanowią one jedno z ważniejszych podejść służących doskonaleniu procesów i zarządzania procesami w organizacjach. Wzrasta też liczba prezentowanych badań, które klasyfikują organizacje na poszczególnych poziomach dojrzałości procesowej ${ }^{10}$. Identyfikowane są przy tym determinanty dojrzałości oraz proponowane nowe modele.

W ocenie dojrzałości procesowej pomocna jest skala ujęta w modelu dojrzałości CMMI (Capability Maturity Model Integration), stworzonym przez amerykańską instytucję Software Engineering Institute. CMMI jest kontynuacją dzieła z lat dziewięćdziesiątych XX wieku - teorii CMM (Capablility Maturity Model). Zgodnie z tym modelem poziom dojrzałości procesowej w organizacji może zostać oceniony według kolejnych poziomów ${ }^{11}$. Model ten może mieć zastosowanie w przypadku procesów różnego rodzaju, może służyć też do oceny dojrzałości zarządzania ryzykiem - procesu, który występuje w wielu różnych rodzajach działalności.

\section{Postępowanie i narzędzia badawcze}

Badania poziomu dojrzałości procesu zarządzania ryzykiem są częścią szerszych badań prowadzonych nad kulturą zarządzania ryzykiem w urzędach podstawowych jednostek samorządu terytorialnego w Polsce ${ }^{12}$. Zostały przeprowadzone w roku 2018 w pięćdziesięciu urzędach gmin, które zostały wytypowane w badaniu przesiewowym. W badaniu dojrzałości procesu zarządzania ryzykiem, w celu osiągnięcia maksymalnie wiarygodnych wyników, zastosowano metodę wywiadu bezpośred niego pogłębionego. Kwestionariusz ankiety powstał

8 E. Głuszek, Zarys modelu dojrzałości zarzqdzania ryzykiem reputacji, „Prace Naukowe Uniwersytetu Ekonomicznego we Wrocławiu” 2014, nr 356, s. 50-51.

9 Zob. M. Raczyńska, Modele dojrzałości procesowej organizacji, „Acta Universitatis Nicolai Copernici. Zarządzanie" 2017, R. XLIV, nr 2, s. 61-73.

10 Zob. A. Bitkowska, Ocena dojrzałości procesowej organizacji zgodnie z modelem CMMI, „Ekonomika i Organizacja Przedsiębiorstwa" 2016, nr 10; R. Gabryelczyk, Samoocena w badaniu dojrzałości procesowejorganizacji...; B.T. Kalinowski, Walidacja modelu dojrzałości procesowej - raport z badań, „Acta Universitatis Lodziensis. Folia Oeconomica” 2014, nr 4(304).

11 Szerzej: P. Senkus, Zarządzanie i dowodzenie z wykorzystaniem orientacji procesowej, Wydawnictwo Difin, Warszawa 2013, s. 212 i nast.; W. Wereda, B. Domańska-Szaruga, Kultura zarzq̨dzania ryzykiem (KZR) jako czynnik innowacyjności organizacji, [w:] J. Woźniak, W. Wereda (red.), Mapa ryzyka w zarządzaniu organizacja. W kierunku organizacji opartej na innowacjach i kulturze ryzyka. Studia przypadków oraz dobre praktyki, CeDeWu, Warszawa 2018, s. 83-86.

12 Wyniki szerszych badań w: B. Domańska-Szaruga, Kultura zarzq̨dzania ryzykiem w urzędach podstawowych jednostek samorządu terytorialnego w Polsce, Wydawnictwo Uniwersytetu Przyrodniczo-Humanistycznego w Siedlcach, Siedlce 2019. 
na podstawie autorskiego modelu dojrzałości procesu zarządzania ryzykiem w urzędach gmin, który uwzględnia specyfikę tych jednostek. Model ten został opracowany metodą ekspercką ${ }^{13}$ (rysunek 1, tabela 1). Kwestionariusz składał się z czterdziestu dwóch pytań, które ujęte są w podrozdziale trzecim jako wzorce dla kryteriów oceny dojrzałości procesu zarządzania ryzykiem.

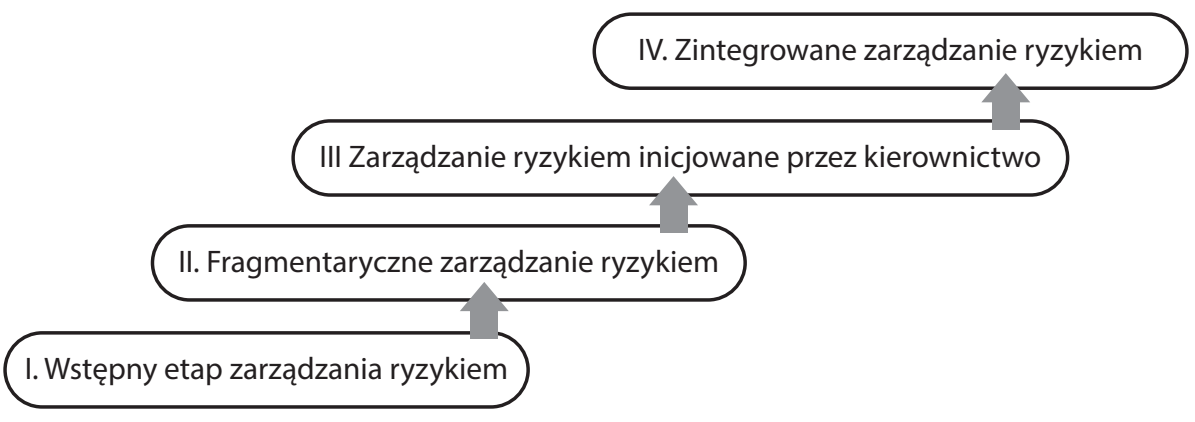

Rysunek 1. Autorski model dojrzałości procesu zarządzania ryzykiem

Źródło: opracowanie własne na podstawie B. Domańska-Szaruga, Kultura zarzqdzania ryzykiem w urzędach podstawowych jednostek samorządu terytorialnego w Polsce, Wydawnictwo Uniwersytetu Przyrodniczo-Humanistycznego w Siedlcach, Siedlce 2019.

13 Wytypowano dwudziestu ekspertów. W skład grupy weszło sześciu profesorów oraz doktorów habilitowanych z zakresu zarządzania oraz innych dyscyplin nauk społecznych, dziesięciu pracowników urzędów gmin zajmujących stanowiska kierownicze oraz czterech konsultantów biznesowych. 
Zastosowanie metody kategoryzacji do oceny dojrzałości procesowej...

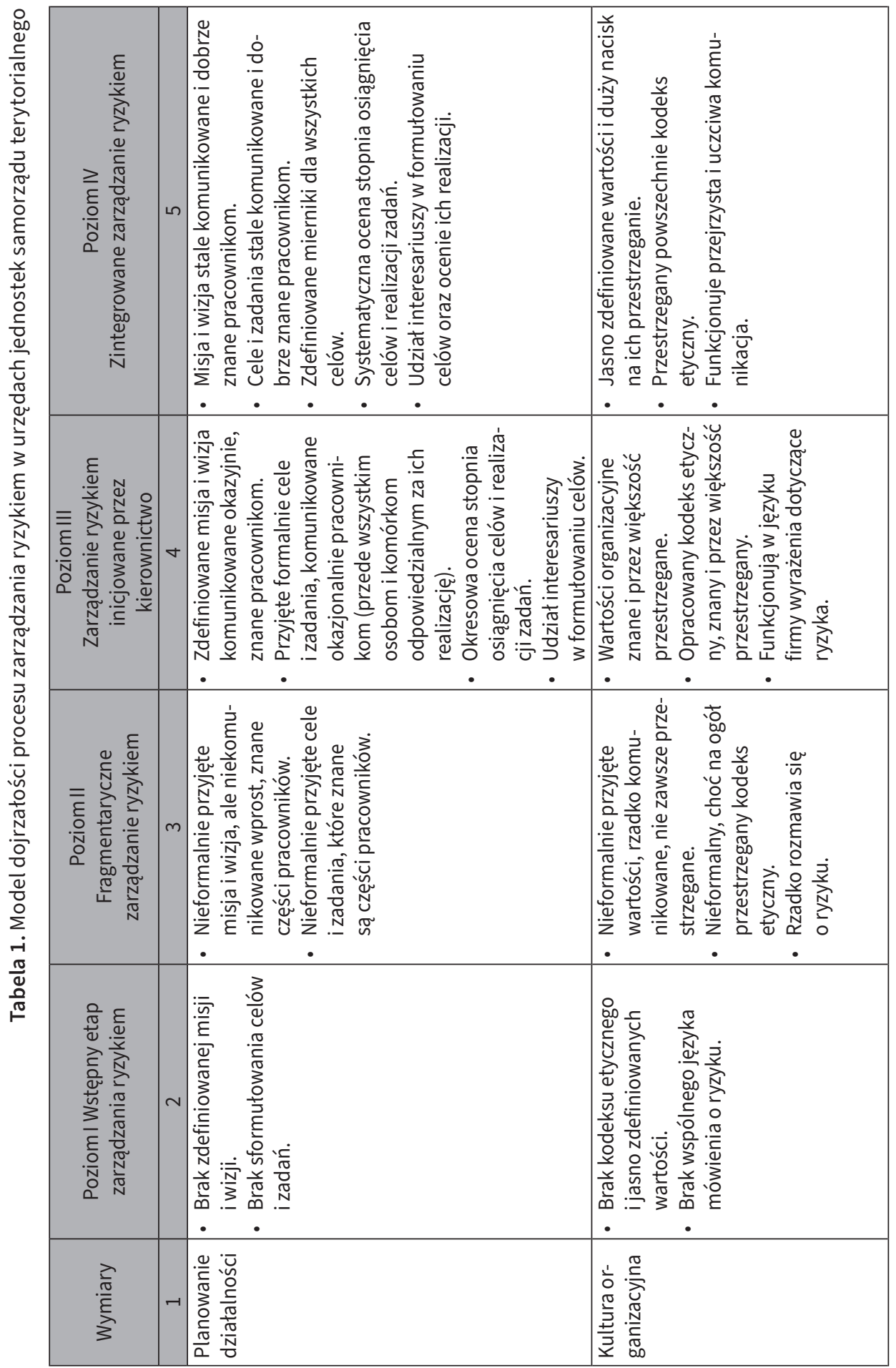




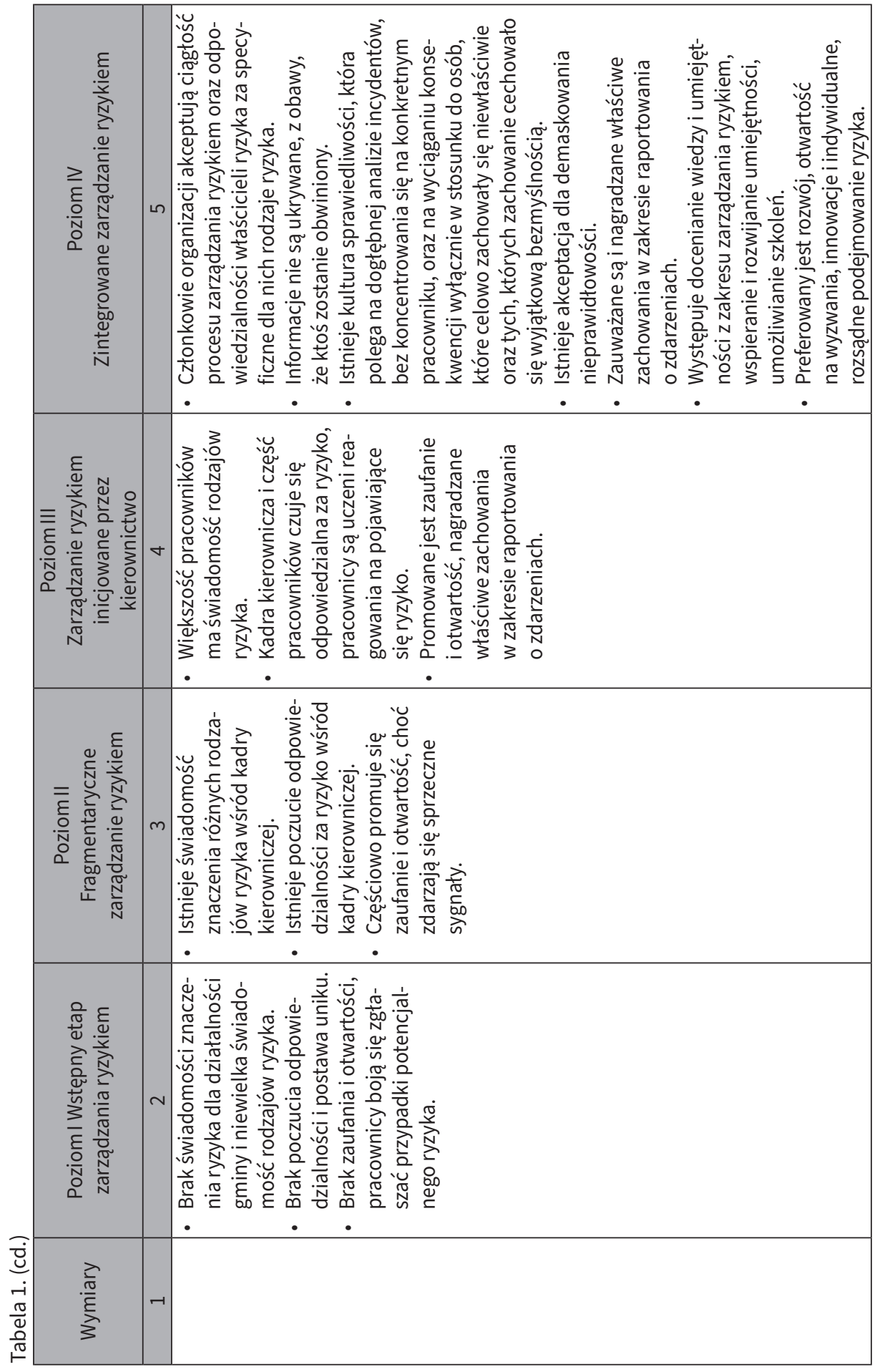




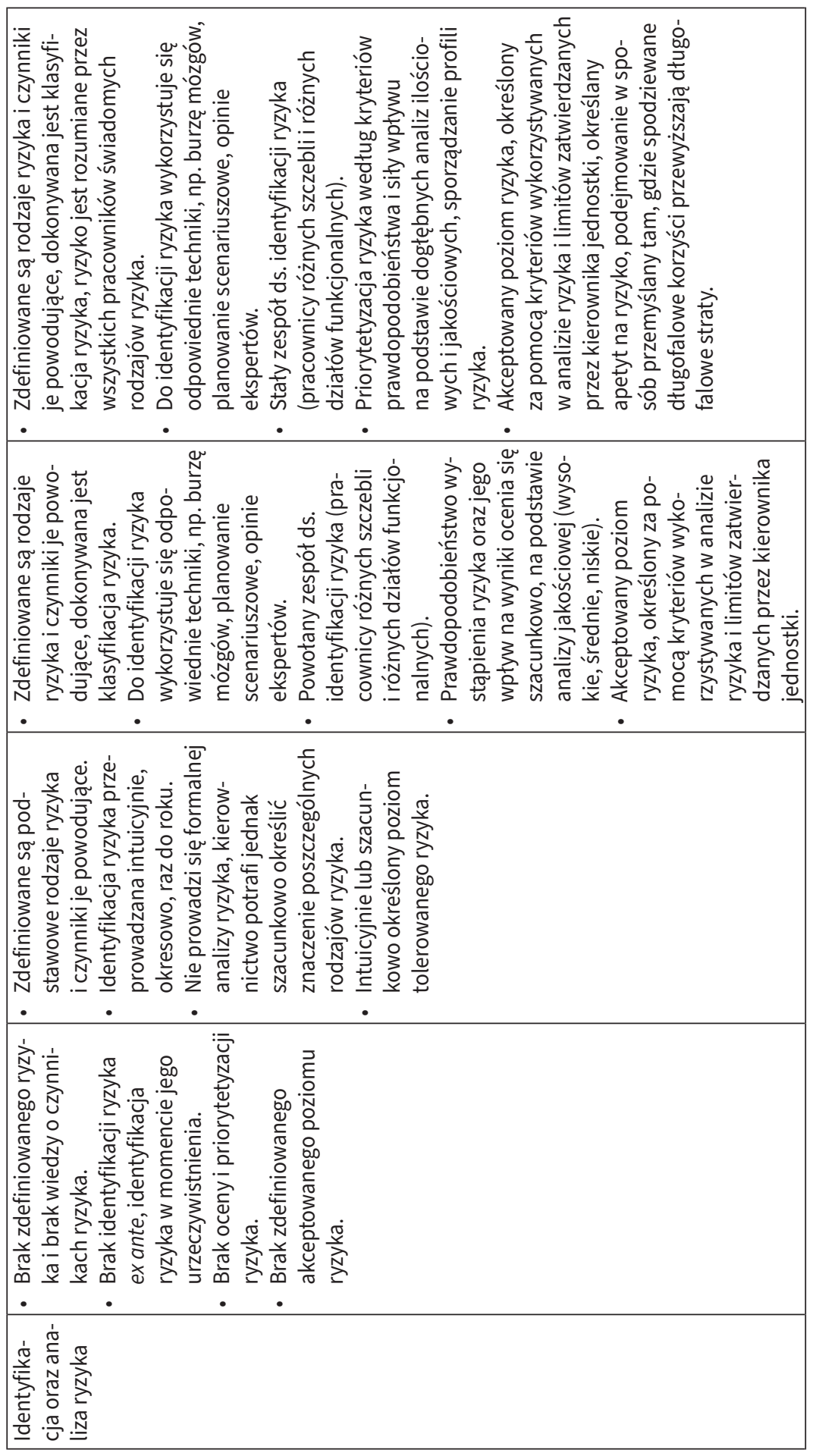




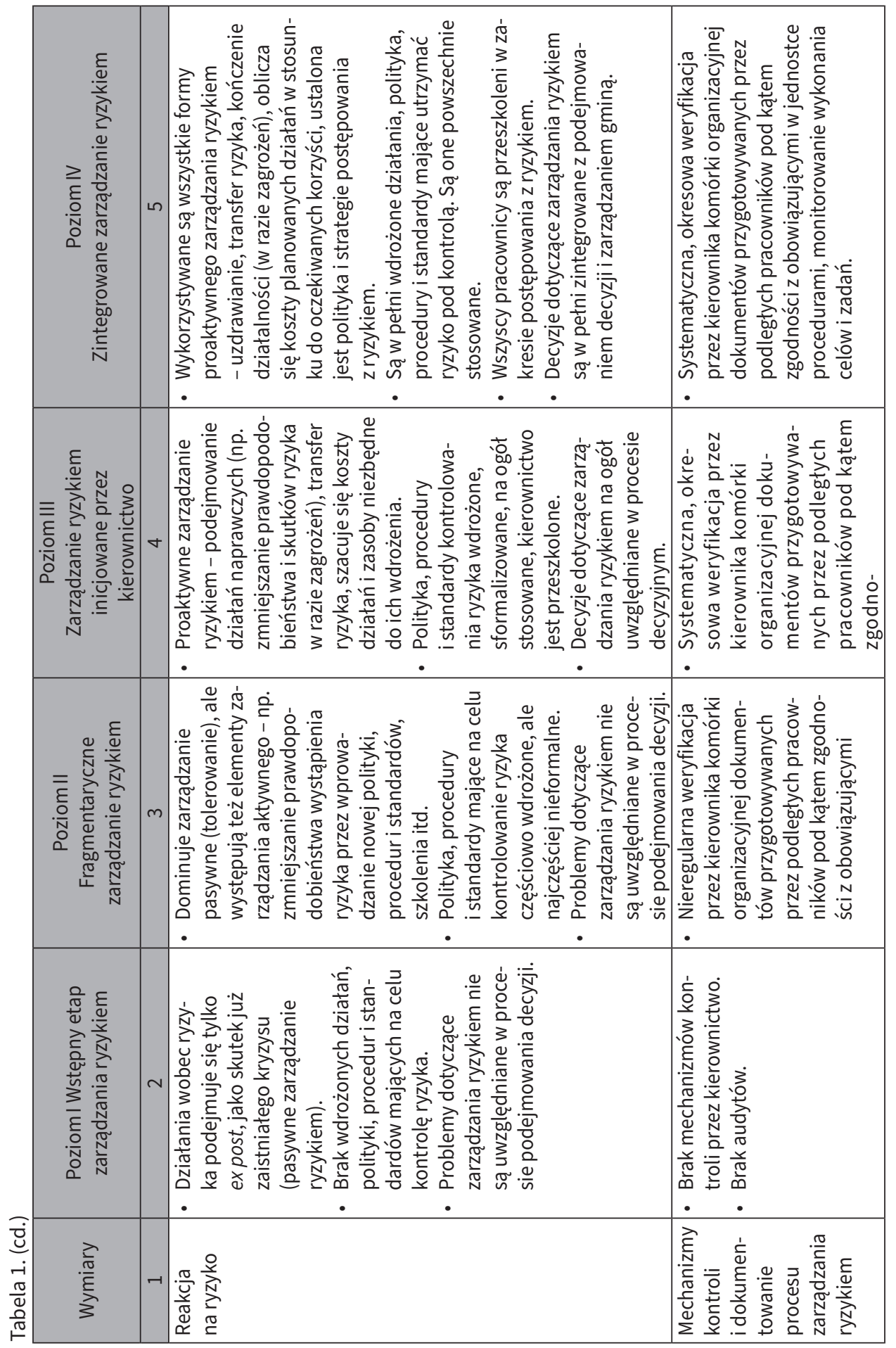




\begin{tabular}{|c|c|}
\hline 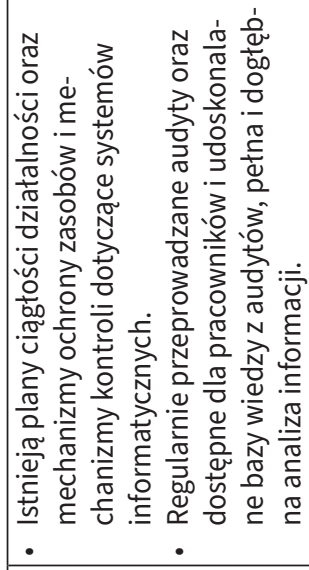 & 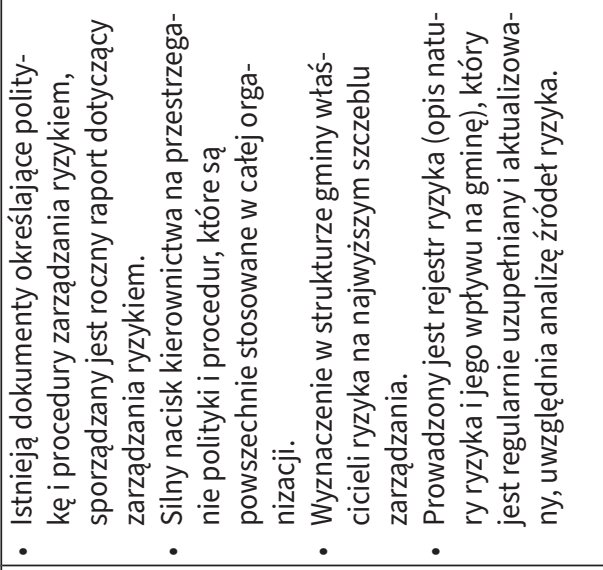 \\
\hline 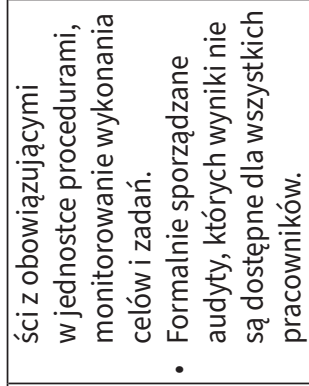 & 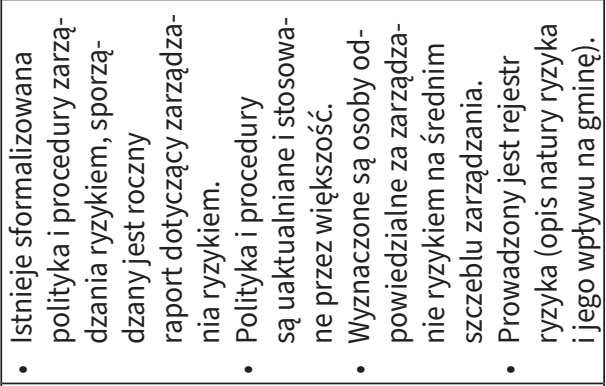 \\
\hline 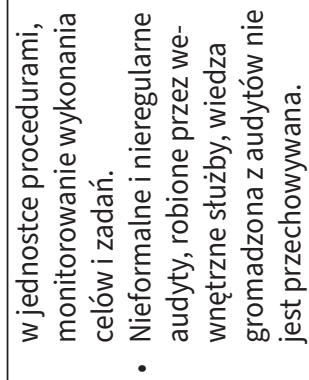 & 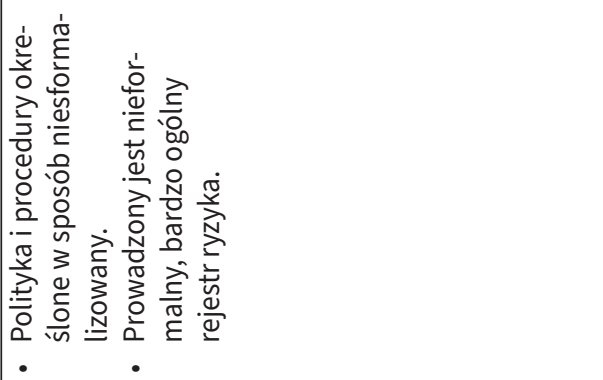 \\
\hline & 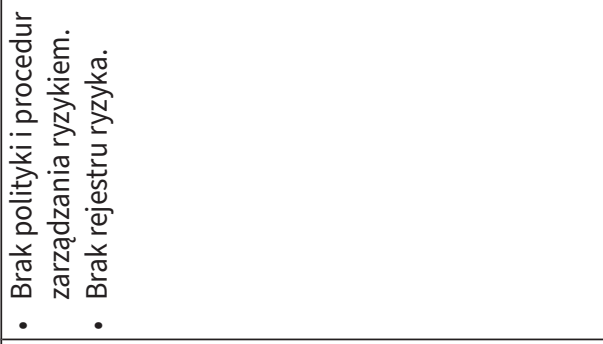 \\
\hline & 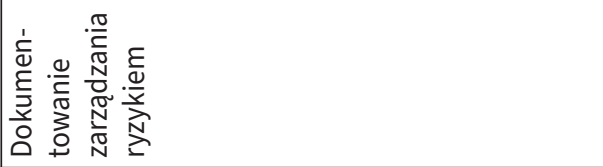 \\
\hline
\end{tabular}




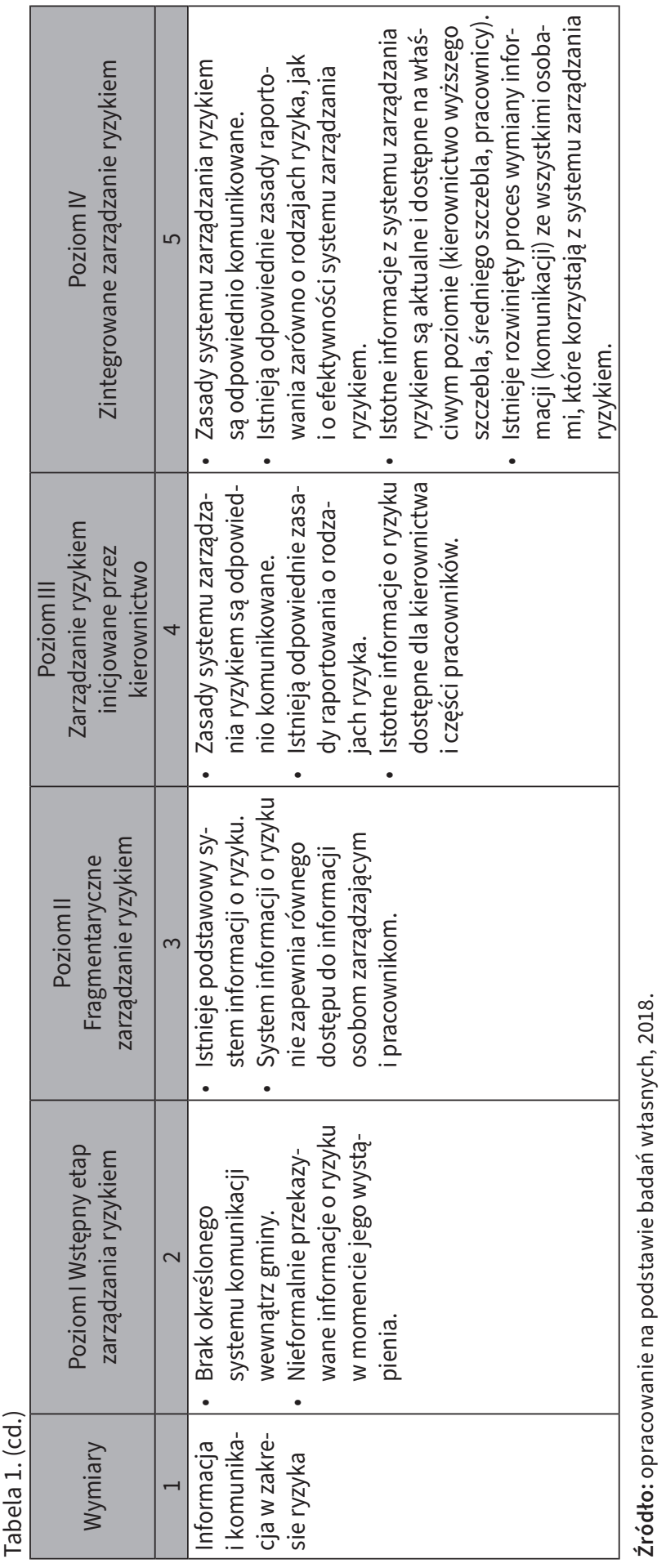




\section{Ocena dojrzatości procesu zarządzania ryzykiem w podstawowych jednostkach samorządu terytorialnego w Polsce}

Wyniki przeprowadzonych badań poziomu dojrzałości procesu zarządzania ryzykiem w urzędach podstawowych jednostek samorządu terytorialnego (gmin) w Polsce opracowano, wykorzystując metodę kategoryzacji, której istotą jest ocena sprawdzająca stanu lub funkcjonowania obiektu (obiektów) badań i jego klasyfikacja jakościowa. Metoda ta została szeroko opisana przez grupę badaczy z Uniwersytetu Ekonomicznego w Krakowie ${ }^{14}$. Rozwinięte postępowanie badawcze kategoryzacji obejmuje następujące etapy:

- określenie struktury kryteriów oceny i wzorców dla kryteriów oceny,

- kwalifikację kryteriów oceny,

- przeprowadzenie oceny sprawdzającej,

- opracowanie regulaminu klasyfikacyjnego.

W pierwszym etapie postępowania badawczego przeprowadzono dobór mierników o charakterze diagnostycznym. Kompleksowa ocena dojrzałości kultury zarządzania ryzykiem wymaga, by struktura kryteriów oceny była różnorodna, ale zarazem należy zadbać o komplementarność poszczególnych kryteriów. Są to bardzo istotne kwestie z punktu widzenia kompleksowości i dokładności analizy diagnostycznej. W postępowaniu badawczym przyjęto strukturę kryteriów oceny zbudowaną na podstawie modelu dojrzałości procesu zarządzania ryzykiem w urzędach jednostek samorządu terytorialnego - poziom IV - zintegrowane zarządzanie ryzykiem. W ten sposób powstało siedem grup kryteriów oceny i wzorców dla kryteriów oceny dojrzałości procesu zarządzania ryzykiem (tabela 2).

14 P. Cabała, C. Mesjasz, H. Piekarz, A. Stabryła, K. Woźniak, Metoda kategoryzacji przedsiębiorstw ze względu na stopień spetniania funkcji gospodarki opartej na wiedzy, [w:] A. Stabryła (red.), Doskonalenie struktur organizacyjnych przedsiębiorstw w gospodarce opartej na wiedzy, Wydawnictwo C.H. Beck, Warszawa 2009. 
Tabela 2. Zestawienie struktury kryteriów oceny i wzorców dla kryteriów oceny dojrzałości procesu zarządzania ryzykiem

K1 - Planowanie działalności

\section{Charakterystyka kryterium}

Planowanie działalności jest procesem, w którym są ustalane cele i zadania oraz wskazywane środki do ich osiągania. Planowanie ma podstawowe znaczenie dla zarządzania jednostką, w tym dla zarządzania ryzykiem. Cele pozwalają skupić wysiłki na wyznaczonych kierunkach działania, co umożliwia efektywną alokację zasobów. Uświadomienie pracownikom celów i zadań jest dla nich źródłem motywacji, pracownicy wiedzą, czego się od nich wymaga. W stosunku do każdego celu należy określić miernik, który pozwoli na rzetelne i obiektywne określenie stopnia realizacji celu. Planowanie powinno uwzględniać specyficzne uwarunkowania, w tym ograniczenia, w ramach których organizacja realizuje określoną strategię.

\section{Wzorce oceny}

Stan wzorcowy organizacja osiąga, gdy:

- misja i wizja są stale komunikowane i dobrze znane pracownikom,

- cele i zadania są stale komunikowane i dobrze znane pracownikom,

- zdefiniowane są mierniki dla wszystkich celów,

- występuje systematyczna ocena stopnia osiągnięcia celów i realizacji zadań,

- interesariusze mają udział w formułowaniu celów oraz ocenie ich realizacji.

\section{K2 - Kultura w organizacji}

\section{Charakterystyka kryterium}

Kryterium stuży do oceny istniejącej kultury organizacji. Kultura organizacji to styl działania organizacji, podzielane przez jej członków poglądy i wartości, wspólne wzory zachowań oraz sposoby komunikacji. Kultura organizacji jest istotną determinantą powodzenia procesu zarządzania ryzykiem, gdyż wpływa bezpośrednio na kształtowanie właściwej dla danej organizacji architektury zarządzania ryzykiem i zasad zarządzania ryzykiem. Odpowiednia kultura organizacji ułatwia organizację procesu zarządzania ryzykiem, w szczególności w obszarze odpowiedzialności członków organizacji za zarządzanie ryzykiem. Postawa wobec ryzyka osoby lub grupy osób związana jest z określonym postrzeganiem ryzyka, czyli z subiektywną oceną ryzyka, jego cech, prawdopodobieństwa występowania i skutków. Ma to wpływ na kulturę zarządzania ryzykiem przez zachowania i postawy osób podejmujących decyzje w warunkach ryzyka i niepewności.

\section{Wzorce oceny}

Stan wzorcowy, czyli kulturę organizacji optymalną z punktu widzenia budowy i doskonalenia kultury zarządzania ryzykiem, organizacja osiąga, gdy:

- wartości są jasno zdefiniowane i istnieje duży nacisk na ich przestrzeganie,

- powszechnie przestrzegany jest kodeks etyczny,

- funkcjonuje przejrzysta i uczciwa komunikacja,

- członkowie organizacji akceptują ciągłość procesu zarządzania ryzykiem oraz odpowiedzialności właścicieli ryzyka za specyficzne dla nich rodzaje ryzyka,

- informacje nie są ukrywane z obawy, że ktoś zostanie obwiniony,

- istnieje kultura sprawiedliwości, która polega na dogłębnej analizie incydentów, bez koncentrowania się na konkretnym pracowniku oraz na wyciąganiu konsekwencji wyłącznie w stosunku do osób, które celowo zachowały się niewłaściwie oraz tych, których zachowanie cechowało się wyjątkową bezmyślnością,

- istnieje akceptacja dla demaskowania nieprawidłowości,

- zauważane są i nagradzane właściwe zachowania w zakresie raportowania o zdarzeniach,

- występuje docenianie wiedzy i umiejętności z zakresu zarządzania ryzykiem, wspieranie i rozwijanie umiejętności, umożliwianie szkoleń,

- preferowany jest rozwój, otwartość na wyzwania, innowacje i indywidualne, rozsądne podejmowanie ryzyka. 
K3 - Identyfikacja oraz analiza ryzyka

\section{Charakterystyka kryterium}

Punkt wyjścia do szczegółowej analizy i trafnej oceny ryzyka w JST stanowi identyfikacja ryzyka. Powinna być ona poprzedzona zrozumieniem celów i zadań jednostki, w tym czynników, które mogą wpłynąć na osiągnięcie zamierzonych celów. Identyfikacja ryzyka powinna być procesem powtarzalnym (systematycznym) i zintegrowanym z procesem planowania działalności. Zidentyfikowane rodzaje ryzyka należy poddać analizie w celu poznania zakresu, w jakim mogą one wpłynąć na realizację celów organizacji. Metodologia oceny ryzyka pozwala na oszacowanie tzw. istotności ryzyka przez określenie prawdopodobieństwa wystąpienia ryzyka i możliwych jego skutków (siły wpływu).

\section{Wzorce oceny}

Stan pożądany z punktu widzenia skuteczności procesu zarządzania ryzykiem ma miejsce, gdy:

- zdefiniowane są rodzaje ryzyka i czynniki je powodujące,

- dokonywana jest klasyfikacja ryzyka,

- pracownicy są świadomi ryzyka i rozumieją je,

- do identyfikacji ryzyka wykorzystuje się odpowiednie techniki, np. burzę mózgów, planowanie scenariuszowe, opinie ekspertów,

- istnieje zespót ds. identyfikacji ryzyka (pracownicy różnych szczebli i różnych działów funkcjonalnych),

- występuje priorytetyzacja ryzyka według kryteriów prawdopodobieństwa i siły wpływu na podstawie dogłębnych analiz ilościowych i jakościowych, sporządzane są profile ryzyka,

- akceptowany poziom ryzyka określony jest za pomocą kryteriów wykorzystywanych w analizie ryzyka i limitów zatwierdzanych przez kierownika jednostki, określany apetyt na ryzyko podejmowane w sposób przemyślany tam, gdzie spodziewane długofalowe korzyści przewyższają dtugofalowe straty.

\section{Charakterystyka kryterium}

W stosunku do każdego istotnego ryzyka jednostka samorządu terytorialnego powinna określić działania, które należy podjąć w celu zmniejszenia danego ryzyka do akceptowanego poziomu.

Wzorce oceny

Stan wzorcowy organizacja osiąga, gdy:

- ustalona jest polityka i strategie postępowania z ryzykiem,

- wykorzystywane są wszystkie formy proaktywnego zarządzania ryzykiem - uzdrawianie, transfer ryzyka, kończenie działalności (w razie zagrożeń),

- oblicza się koszty planowanych działań w stosunku do oczekiwanych korzyści,

- są w pełni wdrożone i powszechnie stosowane działania, polityka, procedury i standardy mające utrzymać ryzyko pod kontrolą,

- wszyscy pracownicy są przeszkoleni w zakresie postępowania z ryzykiem,

- decyzje dotyczące zarządzania ryzykiem są w pełni zintegrowane z podejmowaniem decyzji i zarządzaniem organizacją.

\section{Charakterystyka kryterium}

Mechanizmy kontroli ryzyka stanowią ważną część polityki i procedur, za pomocą których jednostka dąży do osiągnięcia własnych celów i zadań. Organizacja powinna ustanowić mechanizmy, które umożliwią monitorowanie wdrożonych rozwiązań i dokonywanie oceny ich efektywności. Za efektywne należy uznać takie rozwiązania, które sprawiają, że system zarządzania ryzykiem pozwala zwiększyć sprawność zarządzania i prawdopodobieństwo osiągania celów organizacji, zapewniając ciągłość jej działania. Monitorowanie ryzyka powierzane jest zwykle kierownictwu oraz pracownikom na samodzielnych stanowiskach, z zastrzeżeniem, że w procesie tym powinni brać udział wszyscy pracownicy. 
Tabela 2. (cd.)

Wzorce oceny

Stan wzorcowy organizacja osiąga, gdy:

- monitoruje wykonanie zadań i osiąganie celów,

- występuje systematyczna, okresowa weryfikacja przez kierownika komórki organizacyjnej dokumentów przygotowywanych przez podległych pracowników pod kątem zgodności z obowiązującymi w jednostce procedurami,

- istnieją plany ciągłości działalności oraz mechanizmy ochrony zasobów i mechanizmy kontroli dotyczące systemów informatycznych,

- regularnie przeprowadzane są audyty, funkcjonuje pełna i dogłębna analiza informacji,

- istnieją dostępne dla pracowników i udoskonalane bazy wiedzy z audytów.

K6 - Dokumentowanie procesu zarządzania ryzykiem

\section{Charakterystyka kryterium}

Monitorowanie i raportowanie to działania, które mają charakter ciągły i pozwalają na obserwację profilu ryzyka organizacji. Umożliwiają również szybkie wykrycie działań niepożądanych i usprawnienie zarządzania ryzykiem. Monitorowanie ryzyka powierzane jest zwykle kierownictwu oraz pracownikom na samodzielnych stanowiskach, z zastrzeżeniem, że w procesie tym powinni brać udział wszyscy pracownicy.

Wzorce oceny

Stan wzorcowy organizacja osiąga, gdy:

- istnieją dokumenty określające politykę i procedury zarządzania ryzykiem,

- sporządzany jest roczny raport dotyczący zarządzania ryzykiem,

- występuje silny nacisk kierownictwa na przestrzeganie polityki i procedur, które są powszechnie stosowane w catej organizacji,

- w strukturze organizacji wyznaczeni są właściciele ryzyka,

- prowadzony jest rejestr ryzyka (opis natury ryzyka i jego wpływu na organizację), który jest regularnie uzupetniany i aktualizowany, uwzględnia analizę źródet ryzyka.

$$
\text { K7 - Informacja i komunikacja w zakresie ryzyka }
$$

\section{Charakterystyka kryterium}

Czynniki, które mogą negatywnie wpłynąć na realizację celów organizacji, powinny być komunikowane pracownikom poszczególnych komórek organizacyjnych, w których mogą wystąpić. Bez wiedzy o rodzajach zagrożenia nie jest możliwe uczestniczenie w procesie zarządzania ryzykiem i skuteczne działania w tym zakresie. Pracownicy powinni być też informowani o tym, w jaki sposób poszczególne zagrożenia wpływają na realizację celów organizacji. Powinni też mieć świadomość, że między innymi od ich postawy w zakresie komunikowania o ryzyku zależy powodzenie procesu zarządzania ryzykiem i sukces organizacji.

\section{Wzorce oceny}

Stan wzorcowy organizacja osiąga, gdy:

- zasady systemu zarządzania ryzykiem są odpowiednio komunikowane,

- istnieją odpowiednie zasady raportowania zarówno o rodzajach ryzyka, jak i o efektywności systemu zarządzania ryzykiem,

- istotne informacje z systemu zarządzania ryzykiem są aktualne i dostępne na właściwym poziomie (kierownictwo wyższego szczebla, średniego szczebla, pracownicy),

- istnieje rozwinięty proces wymiany informacji (komunikacji) ze wszystkimi osobami, które korzystają z systemu zarządzania ryzykiem.

Źródło: opracowanie własne na podstawie P. Cabała, C. Mesjasz, H. Piekarz, A. Stabryła, K. Woźniak, Metoda kategoryzacji przedsiębiorstw ze względu na stopień spetniania funkcji gospodarki opartej na wiedzy, [w:] A. Stabryła (red.), Doskonalenie struktur organizacyjnych przedsiębiorstw w gospodarce opartej na wiedzy, Wydawnictwo C.H. Beck, Warszawa 2009, s. 260. 
Po określeniu wzorców dla kryteriów oceny ustalono wagi dla poszczególnych kryteriów. Wyrażają one znaczenie danego kryterium dla dojrzałości procesu zarządzania ryzykiem. W prezentowanych badaniach wagi zostały określone przez zespół ekspertów. Eksperci przyporządkowali poszczególnym kryteriom oceny wagi w skali trzypunktowej (tabela 3).

Tabela 3. Zestawienie wag dla kryteriów oceny

\begin{tabular}{|l|c|}
\hline \multicolumn{1}{|c|}{ Kryterium } & Waga \\
\hline K1 - Planowanie działalności & 3 \\
K2 - Kultura w organizacji & 3 \\
K3 - Identyfikacja oraz analiza ryzyka & 3 \\
K4 - Reakcja na ryzyko & 2 \\
K5 - Mechanizmy kontroli & 2 \\
K6 - Dokumentowanie procesu zarządzania ryzykiem & 2 \\
K7 - Informacja i komunikacja w zakresie ryzyka & 2 \\
\hline
\end{tabular}

Źródło: opracowanie własne.

Wyniki badań (wywiad bezpośredni) zostały porównane ze skonstruowanym wzorcem określającym stan pożądany - tzw. aspektami preferencyjnymi, określonymi w zestawieniu struktury kryteriów oceny i wzorców dla kryteriów oceny dojrzałości procesu zarządzania ryzykiem jako wzorce oceny. Wynikiem tego porównania (oceny sprawdzającej) jest przyznanie poszczególnym kryteriom punktów w skali od 0 do 8 według skonstruowanej tabeli przeliczników (tabela 4). Dalsze postępowanie to ustalenie wyniku osiągniętego przez dany urząd gminy na podstawie skali pomiarowej. Interpretacja wyników umożliwia określenie poziomu dojrzałości kultury zarządzania ryzykiem w tym urzędzie.

Tabela 4. Tabela przeliczników (skala pomiarowa) dla wzorców oceny dojrzałości procesu zarządzania ryzykiem

\begin{tabular}{|c|c|c|c|c|c|c|c|c|c|}
\hline \multirow{2}{*}{$\begin{array}{c}\text { Kryteria } \\
\text { oceny }\end{array}$} & $\begin{array}{c}\text { Stan } \\
\text { niedosta- } \\
\text { teczny }\end{array}$ & $\begin{array}{c}\text { Stan } \\
\text { mierny }\end{array}$ & $\begin{array}{c}\text { Stan } \\
\text { dopusz- } \\
\text { czalny }\end{array}$ & $\begin{array}{c}\text { Stan } \\
\text { dosta- } \\
\text { teczny }\end{array}$ & $\begin{array}{c}\text { Stan } \\
\text { średni }\end{array}$ & $\begin{array}{c}\text { Stan } \\
\text { dobry }\end{array}$ & $\begin{array}{c}\text { Stan } \\
\text { więcej niż } \\
\text { dobry }\end{array}$ & $\begin{array}{c}\text { Stan } \\
\text { bardzo } \\
\text { dobry }\end{array}$ & $\begin{array}{c}\text { Stan } \\
\text { wyróż- } \\
\text { niający }\end{array}$ \\
\hline & 0 & 1 & 2 & 3 & 4 & 5 & 6 & 7 & 8 \\
\hline
\end{tabular}

Źródto: opracowanie własne.

Biorąc pod uwagę przedstawione kryteria oceny, ustalono wartość indeksu dojrzałości procesu zarządzania ryzykiem (DKPR) według wzoru:

$$
D P Z R_{i}=\sum_{j=1}^{n} w_{j} \cdot q_{i j}
$$


gdzie:

$w_{j}$ - waga $j$-tego kryterium oceny,

$q_{i j}$ - punktowa ocena sprawdzająca odniesiona do $i$-tego urzędu gminy,

$i=1, \ldots, m$ - urzędy gmin,

$j=1, \ldots, n-$ kryteria oceny.

Badaniu poddano 50 urzędów gmin. Po ustaleniu dla każdego urzędu gminy wartości indeksu dojrzałości kultury zarządzania ryzykiem (maksymalna wartość $D P Z R=48$ ) opracowano regulamin kwalifikacyjny, który jest sformalizowanym ujęciem zasad i warunków ustalania kategorii urzędu gminy ze względu na osiągnięty poziom dojrzałości kultury zarządzania ryzykiem. W regulaminie kwalifikacyjnym określono skalę wartościującą, przedziały hierarchiczne indeksu DKZR oraz oznaczono kategorie obiektów (urzędów gmin). Przedziałom hierarchicznym odpowiadają poziomy dojrzałości kultury zarządzania ryzykiem (tabela 5).

Tabela 5. Przedziały hierarchiczne indeksu DKZR

\begin{tabular}{|l|c|c|}
\hline \multicolumn{1}{|c|}{ Poziom dojrzałości } & $\begin{array}{c}\text { Punktacja } \\
\text { (wartość indeksu DKZR) }\end{array}$ & $\begin{array}{c}\text { Liczba } \\
\text { urzędów gmin }\end{array}$ \\
\hline $\begin{array}{l}\text { Poziom I - Wstępny etap } \\
\text { zarządzania ryzykiem }\end{array}$ & $\begin{array}{c}\text { Wartość indeksu DKZR poniżej 40\% wartości } \\
\text { maksymalnej }\end{array}$ & 3 \\
\hline $\begin{array}{l}\text { Poziom II - Fragmentaryczne } \\
\text { zarządzanie ryzykiem }\end{array}$ & $\begin{array}{c}20-28 \\
\text { Wartość indeksu DKZR w granicach 40-59\% } \\
\text { wartości maksymalnej }\end{array}$ & 16 \\
\hline $\begin{array}{l}\text { Poziom III - Zarządzanie } \\
\text { ryzykiem inicjowane przez } \\
\text { kierownictwo }\end{array}$ & $\begin{array}{c}\text { Wartość indeksu DKZR w granicach 60-79\% } \\
\text { wartości maksymalnej }\end{array}$ & 26 \\
\hline $\begin{array}{l}\text { Poziom IV - Zintegrowane } \\
\text { zarządzanie ryzykiem }\end{array}$ & $\begin{array}{c}39-48 \\
\text { Wartość indeksu DKZR w powyżej 80\% } \\
\text { wartości maksymalnej }\end{array}$ & 5 \\
\hline
\end{tabular}

Źródto: opracowanie na postawie badań własnych, 2018.

Obliczenie indeksu $D K Z R$ dla każdego z badanych urzędów gmin jest ostatnim etapem procesu kategoryzacji. Wyniki kategoryzacji przedstawiono $\mathrm{w}$ formie graficznej (w ujęciu procentowym) na rysunku 2.

Badania dotyczące dojrzałości procesu zarządzania ryzykiem w urzędach gmin w Polsce wskazują, że największy odsetek urzędów (52\%) osiąga III poziom dojrzałości - Zarządzanie ryzykiem inicjowane przez kierownictwo. Poziom ten cechuje przede wszystkim zidentyfikowany kontekst zarządzania ryzykiem, opracowane i przyjęte w całej organizacji wspólne podejście do oceny ryzyka, opracowanie planów działania w odpowiedzi na zagrożenia o wysokim priorytecie, raportowanie do kadry kierowniczej o najważniejszych zagrożeniach. 


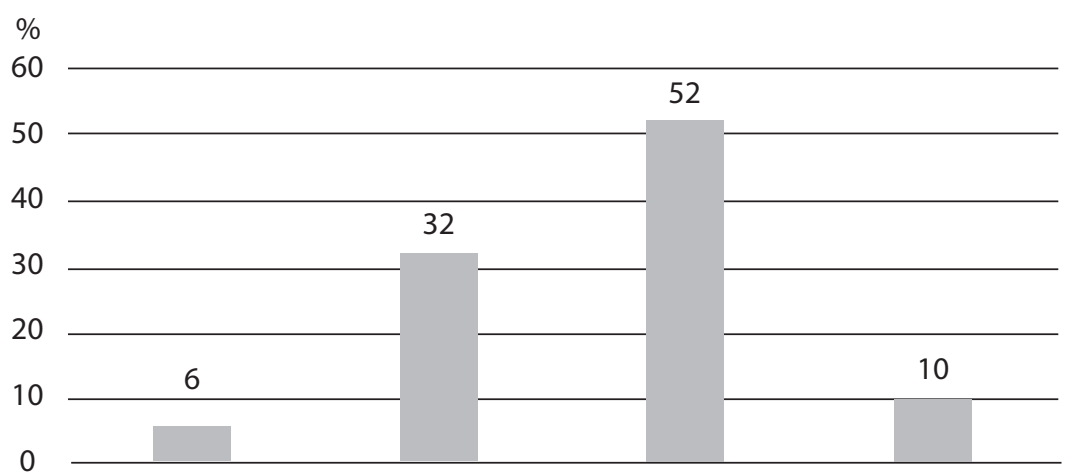

Rysunek 2. Rozkład badanych urzędów gmin pod względem poziomu dojrzałości procesu zarządzania ryzykiem $(N=50)$

Źródło: opracowanie na postawie badań własnych, 2018.

\section{Zakończenie}

Dojrzałość oznacza gotowość do określonych zadań, nabywaną zwykle w procesie rozwoju, co w odniesieniu do organizacji należy rozumieć jako stopniowe doskonalenie pewnych umiejętności i osiąganie szczególnych cech. Zastosowanie narzędzia samooceny do zbadania dojrzałości procesowej organizacji, jej procesów lub obszarów procesowych pozwala osiągnąć wiele korzyści związanych z monitorowaniem postępu we wdrażaniu inicjatyw procesowych i podnoszeniu dojrzałości procesów w celu dalszego rozwoju.

Przedstawiony w artykule model jest propozycją skierowaną do organizacji, które chcą w sposób systematyczny dokonywać oceny dojrzałości swoich procesów. Przykład oceny procesu zarządzania ryzykiem wynika z obszaru zainteresowań autorki i należy podkreślić, że każda organizacja może na własne potrzeby i z uwzględnieniem swoich specyficznych uwarunkowań zbudować model, który będzie z powodzeniem wykorzystywany w doskonaleniu każdego z jej procesów.

\section{Bibliografia}

Bitkowska A., Ocena dojrzałości procesowej organizacji zgodnie z modelem CMMI, „Ekonomika i Organizacja Przedsiębiorstwa" 2016, nr 10, s. 3-12.

Cabała P., Mesjasz C., Piekarz H., Stabryła A., Woźniak K., Metoda kategoryzacji przedsiębiorstw ze względu na stopień spetniania funkcji gospodarki opartej na wiedzy, [w:] Stabryła A. (red.), Doskonalenie struktur organizacyjnych przedsiębiorstw w gospodarce opartej na wiedzy, Wydawnictwo C.H. Beck, Warszawa 2009, s. 241-264. 
Domańska-Szaruga B., Kultura zarządzania ryzykiem w urzędach podstawowych jednostek samorzqdu terytorialnego w Polsce, Wydawnictwo Uniwersytetu Przyrodniczo-Humanistycznego w Siedlcach, Siedlce 2019.

Gabryelczyk R., Samoocena w badaniu dojrzałości procesowej organizacji: studium empiryczne, „Ekonomika i Organizacja Przedsiębiorstwa” 2016, nr 12, s. 67-78.

Głuszek E., Zarys modelu dojrzałości zarzq̨dzania ryzykiem reputacji, „Prace Naukowe Uniwersytetu Ekonomicznego we Wroctawiu" 2014, nr 356, s. 50-71.

Grajewski P., Organizacja procesowa, Polskie Wydawnictwo Ekonomiczne, Warszawa 2007.

Grajewski P., Procesowe zarzq̨dzanie organizacja, Polskie Wydawnictwo Ekonomiczne, Warszawa 2012.

Kalinowski B.T., Walidacja modelu dojrzatości procesowej - raport z badań, „Acta Universitatis Lodziensis. Folia Oeconomica” 2014, nr 4(304), s. 81-92.

Kwintowski A., Samoocena jako narzędzie doskonalenia, „Prace Naukowe Uniwersytetu Ekonomicznego we Wroctawiu” 2015, nr 376, s. 346-356.

Raczyńska M., Modele dojrzałości procesowej organizacji, „Acta Universitatis Nicolai Copernici. Zarządzanie" 2017, R. XLIV, nr 2, s. 61-73.

Ritchie L., Dale B.G., Self-assessment using the business excellence model: A study of practice and process, „International Journal of Production Economics” 2000, vol. 66, s. 241-254.

Röglinger M., Pöppelbuß J., Becker J., Maturity models in business process management, „Business Process Management Journal" 2012, vol. 18, no. 2, s. 328-346.

Senkus P., Zarządzanie i dowodzenie z wykorzystaniem orientacji procesowej, Wydawnictwo Difin, Warszawa 2013.

Warwood, S., Antony, J., A simple, semi-prescriptive self-assessment model for TQM, „Quality Assurance" 2003, vol. 10, s. 67-81.

Wereda W., Domańska-Szaruga B., Kultura zarządzania ryzykiem (KZR) jako czynnik innowacyjności organizacji, [w:] Woźniak J., Wereda W. (red.), Mapa ryzyka w zarzq̨dzaniu organizacją. W kierunku organizacji opartej na innowacjach i kulturze ryzyka. Studia przypadków oraz dobre praktyki, CeDeWu, Warszawa 2018, s. 67-87.

\section{Streszczenie}

Celem artykułu jest przedstawienie propozycji metody oceny dojrzałości procesów w organizacji na podstawie autorskiego modelu dojrzałości procesu zarządzania ryzykiem w urzędach jednostek samorządu terytorialnego w Polsce. Zaprezentowano też wyniki badań dojrzałości procesu zarządzania ryzykiem w tych jednostkach. Badania przeprowadzone zostały w roku 2018 metodą wywiadu bezpośredniego pogłębionego oraz opracowane z wykorzystaniem metody kategoryzacji. Ich wyniki zostały przedstawione syntetycznie w sposób graficzny, natomiast w zakończeniu wskazano na praktyczne zastosowanie przedstawionej propozycji.

Słowa kluczowe: proces zarządzania ryzykiem, dojrzałość procesu, model dojrzałości procesowej, samoocena dojrzałości procesowej, metoda kategoryzacji 


\section{Application of the categorization method to assess the maturity of processes on the example of the risk management process}

\section{Abstract}

The purpose of the study is to present a proposal for a method of the assessing the maturity of processes in an organization based on the author's model of process maturity of the risk management in the offices of local government units in Poland. The results of studies on the process maturity of the risk management in the units were also presented. The research was conducted in 2018 with the in-depth interview method and developed by using the categorization method. The results of the research were presented synthetically in a graphic manner, while in conclusions the practical application of the presented proposal was pointed out.

Keywords: risk management process, process maturity, process maturity model, self-assessment of process maturity, categorization method 